\title{
Menneskelivet bak prostitusjonen
}

\author{
Når prostitusjon tas opp i mediene, illustreres det ofte med bilder av kvinner på mørke gatehjørner - \\ ansiktsløse, anonyme og tragiske. Bak disse bildene finnes menneskeliv få vet noe om.
}

\author{
Ida Elin Kock \\ ida.kock@vel.oslo.kommune.no \\ Azza El Nadjar
}

I denne artikkelen vil vi gi et innblikk i noen av disse livene gjennom fiktive pasienthistorier basert på våre erfaringer med migrerte kvinner vi møter på Pro Sentret, en «drop in»-klinikk for personer som selger seksuelle tjenester i Oslo.

Prostitusjonsmarkedet har det siste tiåret vært i stor forandring. Personene som brukte Pro Sentrets tilbud tidligere, var i hovedsak norske kvinner med rusproblematikk, men siden tidlig på 2000-tallet har antallet migrerte kvinner vokst eksplosjonsartet (1-3). I 2014 hadde $90 \%$ av våre pasienter annen opprinnelse enn norsk (1). Denne forholdsvis raske forandringen har ført til at vi har tilpasset våre helsetjenester - for på best mulig måte å imøtekomme de særskilte behovene denne gruppen har. En utfordring i møtet med denne pasientgruppen finnes selvfølgelig i språket. Ofte har pasientene dårlige ferdigheter i både norsk og engelsk, og grunnet uforutsigbarheten - pasientene benytter seg vanligvis ikke av timebestilling - er det vanskelig å ha en tolk til stede. Vi er derfor mange ganger henvist til å bruke mimikk og kroppsspråk for å kommunisere. En større utfordring befinner seg i den sosiokulturelle sfæren, og det er fremfor alt den vi kommer til å berøre i denne artikkelen.

\section{Helsetjeneste «by proxy»}

De migrerte pasientenes oppholdsgrunnlag i Norge varierer. Enkelte av dem har, vanligvis gjennom ekteskap med en norsk mann, norsk statsborgerskap. Mange har opphold $i$ et annet Schengen-land, mens andre er her illegalt. Noen bruker Pro Sentret som et spesialtilpasset supplement til ordinære helsetjenester, men i mange tilfeller er vårt tilbud en av meget få muligheter til å få til hjelp utover øyeblikkelig helsehjelp.

Uansett oppholdsgrunnlag preges pasientenes liv ofte av stress, dårlig kosthold, uro over familie i hjemlandet, økonomi og boligsituasjon. Mange av de helserelaterte problemene pasientene søker hjelp for, er derfor stress- og livsstilsrelaterte, snarere enn en følge av sexsalget i seg selv. Mange ganger finnes det en tilleggsproblematikk i form av dårlige erfaringer med helsetjenesten i hjemlandet, som ofte er dyr og mangelfull. Når man da, kanskje for første gang, tilbys helsetjenester av høy kvalitet som dessuten er gratis, kan ønsket om å strekke tilbudet til de pårørende i hjemlandet bli stort:

Nigeriansk pasient kommer inn med ustabilt blodtrykk. Da jeg skal ta opp anamnese, forteller pasienten plutselig at hun nettopp har fått en telefonsamtale fra Nigeria og at sønnen hennes er på sykehus. Sønnen har i en lengre periode hatt gjentakende konvulsjoner og drar inn og ut av sykehus uten at noen finner en forklaring. Pasienten er fortvilet og forteller at hun ikke stoler på sykehussystemet i Nigeria - legene er ikke flinke og tar ikke sønnen hennes på alvor. Hun vil at jeg skal skrive ut medisin til sønnen hennes. Jeg forteller at jeg ikke har anledning til det og prøver å snakke om hennes blodtrykk. Pasienten mener at det ustabile blodtrykket kommer av hennes uro for sønnen. Det er ikke noe å gjøre hvis ikke sønnen blir frisk.

I eksemplet prøver altså pasienten å forlenge helsetilbudet hun har, til familien i hjemlandet som en slags legetjeneste «by proxy». Eksemplet viser også hvordan pasientens helse er relatert til familiens situasjon i hjemlandet. Motivasjonen for å dra tusentalls mil for å selge seksuelle tjenester i Europa, er nesten så godt som alltid et ønske om å skape et bedre liv for seg selv og sine nærmeste. Samtidig skaper avstanden, og uroen for familien som er igjen, en uutholdelig tilværelse som får store konsekvenser for den psykiske, men også for den fysiske helsen hos pasientene.

\section{Seksuell og reproduktiv helse}

I diskusjoner rundt kvinners sårbarhet i prostitusjon tenderer offentlig dialog til å rette søkelyset mot utsattheten i relasjonen til kunder. Flere studier har vist at sårbarheten for seksuelle infeksjoner og andre risikoer knyttet til seksuell atferd hos personer som selger sex, ikke nødvendigvis ligger utelukkende i kunderelasjonen $(4,5)$. Det å se på prostitusjonen som den eneste problematiske variabelen i disse pasientenes liv, vil derfor være utilstrekkelig.

Shannon og medarbeidere (6) viser til strukturelle determinanter for sårbarhet for hivinfeksjon hos personer som selger seksuelle tjenester. Faktorer som påvirket risikoatferd, var blant annet tidligere erfaring av kjønnsbasert vold, økonomisk utsatthet og ustabil boligsituasjon. Dette samsvarer med vår erfaring på Pro Sentret. Mange har en lang historie bestående av omsorgssvikt, kjønnsbasert vold, mangelfull utdanning og økonomisk utsatthet fra langt før prostitusjonsdebuten.

Graviditetsstatistikken til Pro Sentret kan gi en indikasjon på hvilke relasjoner den seksuelle risikoatferden er konsentrert rundt hos våre pasienter. I 12 av de 75 registrerte graviditetene i 2014 oppgis en kunde som far til barnet (1). Vanligvis oppgis en kjæreste som barnefar, men som eksemplet nedenfor indikerer, er betydningen av begrepet «kjæreste» flytende og kan inneholde større eller mindre grad av tvang og utnyttelse.

Rumensk pasient, 19 år. Gråter og er fortvilet. Hun har testet positivt for graviditet. Pasienten har gjentakende ganger fått påvist seksuelt overførbare infeksjoner hos oss. Jeg har fortalt henne om potensielle komplikasjoner av slike infeksjoner for hennes reproduktive evne. Jenta er blitt veldig lei seg for dette og fortalt at det er viktig for henne å ha barn. Men kjæresten vil tape penger hvis hun bærer frem barnet, og han vil at hun skal avbryte svangerskapet. Kjæresten hennes er den som tar slike beslutninger, mener hun. Jeg prøver å fortelle henne at det kun er hun som kan ta slike beslutninger, men hun skjønner det ikke. Jenta snakker om dette som et slags regelverk hun må følge, og hun viser ikke noe tegn til å se på seg selv som et autonomt individ. Jeg bestiller time for abort.

Sosiologen Teela Sanders (2002) mener at kondomet fungerer som «psykologisk barriere» mellom intimitet, følelsesmessig nærhet og den instrumentelle, kommersielle seksualiteten for sexselgere. Det å bruke kondom i en privat seksuell relasjon vil innebære en påminnelse om den «kliniske» sexakten de tilbyr kunder $(7,8)$. Dette ser 


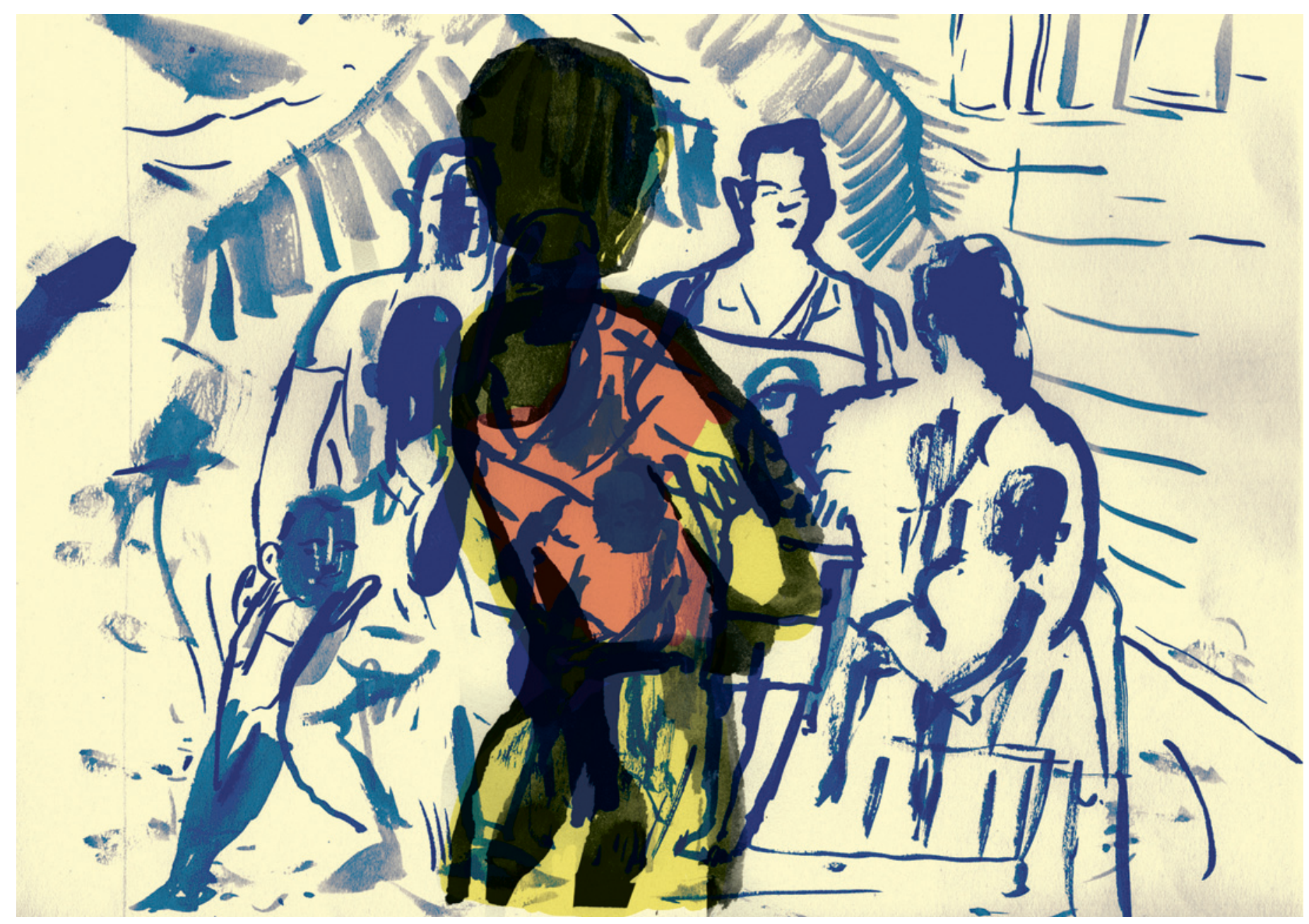

Illustrasjon: Mari Kanstad Johnsen

vi også eksempler på hos oss. Når vi spør pasienter om de har hatt ubeskyttet samleie $i$ det siste, hender det at de svarer nei. Om vi stiller spørsmålet på nytt, men formulerer det som «samleie uten kondom», kan vi få svar som «bare med kjæresten da». Pasientene kan altså ha vanskelig for å forstå at ubeskyttet samleie også omfatter sex med kjæresten. For våre pasienter kan dette være noe de kun tenker på i forbindelse med kunderelasjoner.

«Har jeg evnen til å bli gravid?» er et av de vanligste spørsmålene vi får av pasientene. Våre pasienter føler ofte en sterk uro over sin seksuelle helse, særlig den påvirkning sexarbeidet kan ha på deres reproduktive evne. Ettersom vi ikke kan tilby fertilitetstesting, føler visse av pasientene seg nødt til å prøve å bli gravide for å se om det er mulig. Dersom deres livssituasjon er vanskelig, er det oftest slik at disse pasientene ender opp med en henvisning til svangerskapsavbrudd. Dette illustrerer ikke at pasientene er ustadige og slurvete. Snarere viser den akkurat hvor sentral den repro- duktive evnen er for disse kvinnenes forståelse av seg selv. En del av forklaringen til dette ligger $i$ at mange pasienter kommer fra kulturer der kvinnens verdi ofte er relatert til hennes reproduktive evne, og infertilitet kan være svært stigmatiserende.

En annen utfordring er forestillinger som vanskeliggjør våre forsøk på å overbevise pasientene om betydningen av å bruke hormonell prevensjon. Vanligvis skyldes dette oppfatninger om at slike prevensjonsmidler påvirker den reproduktive evnen negativt på sikt, men det kan også være uro for f.eks. vektoppgang som gjør pasienten skeptisk til slike prevensjonsmidler. I tillegg finnes det mer kulturelt betingede forestillinger. Benedicte Næss Hafskjold viser, i en masteroppgave basert på feltarbeid ved helseavdelingen på Pro Sentret, sammenhengen mellom motstand til hormonell prevensjon og kulturelle forestillinger om menstruasjon hos nigerianske pasienter (9). Oppfatningen om menstruasjonen som en månedlig renselsesprosess, og vekten som tilskrives regelmessig menstruasjon som indikasjon på fertilitet, gjorde de norske helsearbeidernes forsøk på å overbevise pasientene om de positive effektene av hormonell prevensjon lite effektiv.

\section{Å passe på helsen}

Nigeriansk pasient som etterspør cytologiprøve. Dette er ikke noe som vanligvis blir etterspurt blant pasientene på Pro Sentret, og jeg lurer på hvordan hun er blitt kjent med denne prøven. Pasienten forteller at hun har sett et TV-program om forskjellige typer kvinnekreft og nå vil ta denne prøven. Etter denne pasienten kommer i løpet av noen timer ytterligere tre nigerianske pasienter og etterspør cytologiprøver.

Til tross for den vanskelige livssituasjonen mange av våre pasienter befinner seg $\mathrm{i}$, viser de også påfallende resurssterkhet når det kommer til å ivareta sin helse. Som eksemplet viser, spres kunnskap mange ganger både raskt og effektivt i miljøet. Ofte får pasientene helserelatert informasjon via andre kanaler enn helsepersonell 
på Pro Sentret, for eksempel via et TV-program på morsmålet. Dette kan selvfølgelig også ha problematiske konsekvenser. Det skjer iblant at feilaktig og/eller direkte farlig informasjon spres på denne måten. I kollisjonen mellom to ulike forståelsessystemer av kropp og helse er risikoen stor for misforståelser.

Samtidig ligger det her et potensial for å gjøre helseinformasjonen tilgjengelig på en måte som er tilpasset den sosiokulturelle konteksten pasientene befinner seg i, og dra nytte av den viljen som allerede finnes hos pasientene. På Pro Sentret bruker vi derfor såkalte kulturformidlere - ansatte som både har god kjennskap til kulturen pasientene kommer fra, og norsk helsevesen, språk og kultur.

\section{Det vanskelige liv}

I denne artikkelen har vi kun berørt noen få av problemstillingene vi møter i vår kliniske hverdag. Snarere enn å fokusere på problematikken knyttet til sexsalget i seg selv, har vi prøvd å belyse den sosiokulturelle konteksten pasientene befinner seg $i$, og den særegne situasjonen migrantstatusen genererer. Pasientene vi møter, har, i likhet med andre migranter fra fattige land, grepet en av de få sjansene som fantes for å skape en bedre fremtid for seg og sine nærmeste. Med få muligheter til å ta seg inn på det ordinære arbeidsmarkedet, tar de en til dels farlig og lite attraktiv jobb, med forhåpningen om at deres familie skal slippe å gjøre det samme.

De jobber for mye, de stresser, de savner sin familie, og de prøver å gjøre det beste ut av situasjonen. De er overraskende lik deg og meg.

Pasienthistoriene i denne kronikken er fiktive, men basert på våre erfaringer ved klinikken.

\section{Ida Elin Kock (f. 1978)}

er spesialkonsulent ved Pro Sentret i Oslo og stipendiat i etnologi ved Umeå Universitet, Sverige.

Forfatter har fylt ut ICMJE-skjemaet og oppgir ingen interessekonflikter.

\section{Azza El Nadjar (f. 1970)}

er lege ved Pro Sentret i Oslo, og i Ringerike kommune.

Forfatter har fylt ut ICMJE-skjemaet og oppgir ingen interessekonflikter.
Litteratur

1. Pro Sentret. Året 2014. En oppsummering av aktivitetene ved Pro Senteret. Oslo: Pro Sentret, Oslo kommune, 2014.

2. Kofod J, Dyrvig TF, Markwardt K et al. Prostitution i Danmark. København: SFI - Det nationale forskningscenter for velfærd, 2011

3. Statens offentliga utredningar. Förbud mot köp av sexuell tjänst. En utvärdering 1999-2008. SOU 2010: 49. Stockholm: Fritzes offentliga publikationer, 2010.

4. Vanwesenbeeck I. Another decade of social scientific work on sex work: a review of research 1990-2000. Annu Rev Sex Res 2001; 12: 242-89.

5. Rekart ML. Sex-work harm reduction. Lancet 2005: 366: 2123-34

6. Shannon K, Strathdee SA, Goldenberg SM et al. Global epidemiology of HIV among female sex workers: influence of structural determinants. Lancet 2015; 385: 55-71.

7. Sanders T. The condom as psychological barrier Female sex workers and emotional management. Fem Psychol 2002; 12: 561-6.

8. Brewis J, Linstead S. «The worst thing is the screwing» (1): consumption and management of identity in sex work. Gend Work Organ 2000; 7: 84-97

9. Hafskjold BN. Health behavior among female migrant sex workers in Oslo, Norway. Masteroppgave i internasjonal helse. Oslo: Institutt for allmenn- og samfunnsmedisin, Universitet i Oslo, 2009.

Mottatt 7.5. 2015, første revisjon innsendt 25.6. 2015, godkjent 26.6. 2015. Redaktør: Hanne Støre valeur. 